\title{
Paraneoplastic Autoimmune Neurological Syndromes and the Role of Immune Checkpoint Inhibitors
}

\author{
Sophie L. Duong ${ }^{1,2}$ (1) $\cdot$ Harald Prüss ${ }^{1,2}$ (])
}

Accepted: 6 January 2022 / Published online: 18 January 2022

(c) The Author(s) 2022

\begin{abstract}
The introduction of immune checkpoint inhibitors (ICIs) in oncologic therapies has led to a paradigm shift in cancer treatment. ICIs have increased the overall survival in patients with malignant melanoma, small-cell lung cancer, and many other tumor entities. Despite their clinical benefits, these novel cancer immunotherapies can induce neurological immune-related adverse events (irAEs). Such immune-mediated complications can manifest within the spectrum of paraneoplastic neurological syndromes (PNSs). PNSs are rare immune-mediated complications of systemic cancers that can involve every aspect of the nervous system. The emergence of PNSs with ICI treatment opens further pathways to study the complex immunopathological interplay of cancer immunity, cross-reactive neurological autoimmune phenomena, and effects of ICIs on the immune system. ICI-induced PNSs comprise a diverse antibody repertoire and phenotypic spectrum with severe and life-threatening disease progression in some cases. Timely diagnosis and urgent interventions are pivotal for a favorable neurologic and oncologic outcome. This review focuses on the pathogenesis of cancer immunotherapy and the disruption of immune tolerance in PNSs and provides an overview of the most pertinent clinical manifestations and principles of diagnostic and therapeutic managements in light of the expected increase in PNSs due to the widespread use of ICIs in clinical practice. This review further discusses potential and evolving concepts of therapeutic monoclonal antibodies for the treatment of PNSs.
\end{abstract}

Keywords Paraneoplastic neurological syndromes $\cdot$ Immune checkpoint inhibitors $\cdot$ Neurological adverse events · Autoantibodies $\cdot$ Novel immunotherapies $\cdot$ Biologicals

\section{Introduction}

The adoption of novel cancer immunotherapies in general and notably the rise of ICIs in particular transform the oncologic therapeutic landscape [1]. Recent years have shown that ICIs improve patient survival outcomes and achieve long-term remissions in multiple advanced malignancies such as metastatic melanoma, small-cell lung cancer (SCLC), non-small-cell lung cancer (NSCLC), and Hodgkin lymphoma, among others [1-3]. ICIs constitute monoclonal

Harald Prüss

harald.pruess@charite.de

1 Department of Neurology and Experimental Neurology, Charité Universitätsmedizin Berlin, Corporate Member of Freie Universität Berlin, Humboldt-Universität Berlin, and Berlin Institute of Health, Charitéplatz 1, 10117 Berlin, Germany

2 German Center for Neurodegenerative Diseases (DZNE) Berlin, 10117 Berlin, Germany antibodies that block negative regulators of $\mathrm{T}$ cell activation, thus promoting $\mathrm{T}$ cell-mediated antitumor immune responses to overcome the evasive immune mechanisms of cancer cells [4]. Targets for the therapeutic blockade include the inhibitory immune checkpoints cytotoxic T lymphocyteassociated antigen 4 (CTLA-4) and the programmed cell death protein 1 receptor (PD-1) and its ligand PD-L1 [4].

The clinical benefits of ICI therapy have increased the risk for severe immune-related adverse events (irAEs), resulting from the broad enhancement of endogenous immune responses. ICI-induced irAEs can affect any organ system, including the nervous system [5-7]. Neurological irAEs are rare complications with an estimated overall incidence of $3.8 \%$ with anti-CTLA-4 therapy, $6.1 \%$ with antiPD-1 therapy, and $12 \%$ with a combination of both. Severe neurotoxicities occur in less than $1.0 \%$ of cases [8]. Yet, neurological irAEs are clinically relevant as long-term sequelae remain in $40-60 \%$ of patients and $6-15 \%$ of all neurological toxicities are fatal [9-11]. 


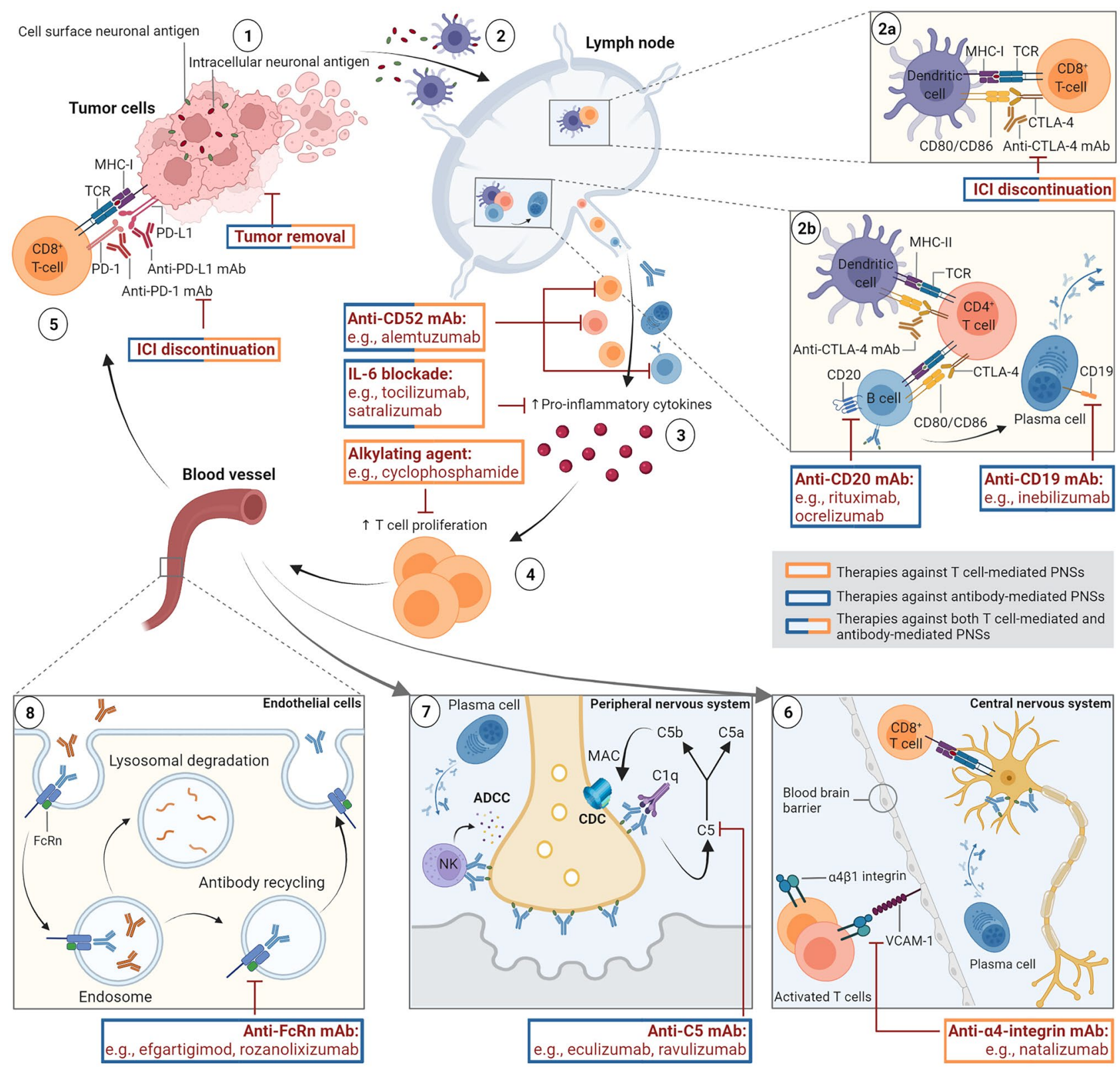

Neurological symptoms usually develop within 3 months of ICI treatment $[5,6,12]$. The clinical features of neurological irAEs can be diverse with multifocal involvement, affecting any part of the nervous system. A subset of ICIrelated neurotoxicities presents as PNSs. These neurotoxicities are of particular clinical concern for their often strikingly rapid clinical deterioration and severe, life-threatening manifestations that are associated with a poor neurological outcome if left untreated [12-14]. Irrespective of ICI treatment, classical PNSs are defined as immune-mediated neurological disorders that can affect any part of the nervous system and demonstrate a tight association with cancer [15]. The widespread use of ICIs in oncology, especially in cancers known for their paraneoplastic association (such as
SCLC), is predicted to increase the incidence of PNSs $[3,16$, 17]. The occurrence of these disorders within the context of such immunotherapies offers new perspectives on studying the immunological mechanisms underlying tumor immune surveillance and the collapse of immune tolerance resulting in PNSs. When PNSs arise as irAEs, it is important to exclude alternative diagnoses to pave the way for further management. The recognition of stereotyped neurological phenotypes, the detection of neuronal autoantibody biomarkers, and specific neuroimaging abnormalities are the pillars of establishing the diagnosis.

This review provides an overview of distinct clinical features of PNSs in the framework of ICI treatment and diagnostic approaches with focus on neuronal antibody 
४Fig. 1 Proposed pathogenic mechanisms of immune checkpoint-inhibitor (ICI)-induced paraneoplastic neurological syndromes (PNSs) and therapeutic strategies. The induction of immune-mediated PNSs under ICI therapy is a multistep process, resulting in the accumulation and amplification of autoreactive cellular and humoral immune responses directed against the central nervous system (CNS) and peripheral nervous system. Tumor neoantigens are released upon tumor necrosis (1). Dendritic cells capture, process and present these cancer-derived neoantigens on major histocompatibility complex (MHC) molecules to naïve $\mathrm{T}$ cells in the lymph nodes (2). Recognition of intracellular neuronal antigens (red ovoid shapes) activates $\mathrm{CD} 8^{+}$cytotoxic $\mathrm{T}$ cells, giving rise to $\mathrm{T}$ cell-mediated PNSs (2a). Cell surface neuronal antigens (green ovoid shapes) are recognized by $\mathrm{CD}^{+} \mathrm{T}$ helper cells that then activate memory B cells and antibody-producing plasma cells, driving antibody-mediated PNSs (2b). ICIs are monoclonal antibodies (mAbs) that block co-inhibitory signals of $\mathrm{T}$ cell activation, including the cytotoxic T lymphocyte antigen 4 (CTLA- 4$)(2 a+b)$, programmed cell death 1 (PD-1) or its ligand PD-L1 (5), resulting in enhanced T cell activation and proliferation. In addition to cellular changes, ICIs increase the production of pro-inflammatory cytokines (3), which can further promote $\mathrm{T}$ cell proliferation (4). Tumor-infiltrating effector $\mathrm{CD}^{+} \mathrm{T}$ cells recognize the cognate antigen, which is presented by MHC I molecules on tumor cells, leading to tumor cell killing (5). If $\mathrm{CD}^{+}$cytotoxic $\mathrm{T}$ cells and antibody-secreting plasma cells travel to the nervous system, they can induce PNSs manifesting as immune-related adverse events (irAEs) under ICI therapy. Autoreactive cytotoxic $\mathrm{CD}^{+} \mathrm{T}$ cells can cross the blood-brain barrier (BBB) and cause direct cytotoxicity and irreversible neuronal cell death in the CNS (6). Autoantibodies targeting cell surface neuronal antigens can cause cell damage via modulation of protein expression and function, antibody-dependent cellular cytotoxicity (ADCC), or complementdependent cytotoxicity (CDC) in the CNS (6) or the peripheral nervous system (7). Endothelial cells can recycle immunoglobulin $\mathrm{G}(\mathrm{IgG})$ autoantibodies with the neonatal $\mathrm{Fc}$ receptor $(\mathrm{FcRn})$ that prevents lysosomal degradation upon binding to the antibody, further contributing to antibody-mediated neuronal damage (8). Therapeutic strategies (red) are guided by the pathogenesis of the PNS and aim at reducing disease-driving autoreactive cytotoxic $\mathrm{T}$ cells (orange boxes) or autoantibodies (blue boxes) (see main text for details). Some therapeutic options reduce both pathogenic $\mathrm{T}$ cells and autoantibodies (mixed orange and blue boxes). ADCC, antibody-dependent cellular cytotoxicity; APC, antigen-presenting cell; $\mathrm{C}$, complement component; $\mathrm{CD}$, cluster of differentiation; CDC, complement-dependent cytotoxicity; CTLA-4, cytotoxic T lymphocyte-associated antigen; FcRn, neonatal $\mathrm{Fc}$ receptor; ICI, immune checkpoint inhibitor, IL, interleukin; mAb, monoclonal antibody; MAC, membrane attack complex; MHC, major histocompatibility complex; NK, natural killer cell; PD-1, programmed cell death protein 1 receptor; PD-L1, programmed cell death protein ligand 1; TCR, T cell receptor VCAM-1, vascular cell adhesion molecule-1. Created with BioRender.com

association. This article further addresses proposed immunopathogenic principles of ICIs as triggers of PNSs, and the derived therapeutic strategies that are most pertinent to the treating neurologist. In view of the expanding indications of ICIs in oncology and the anticipated increased PNSs' prevalence, this review aims to raise awareness among treating clinicians to timely identify these disorders, because if left untreated, PNSs are associated with high morbidity and mortality.

\section{Cancer Immunity and Immunopathology of PNSs}

PNSs are remote complications of systemic cancer that can affect every aspect of the nervous system, including the central nervous system (CNS), the peripheral nervous system, and the neuromuscular junction. These disorders are not directly attributable to the local effects and metastases of the underlying malignancy or indirectly caused by metabolic disturbances, coagulopathies, infections, or treatment-related side effects [15]. Instead, they commonly arise from a crossreactive autoimmune response against shared autoantigens between cancer cells and the neuronal tissue (Fig. 1) [18]. In a first step, ectopically expressed intracellular or cell surface neuronal antigens, including neoantigens resulting from genetic alterations in cancers cells, are released from necrotic tumor cells (Fig. 1(1)). Antigen-presenting cells (APCs), such as dendritic cells, take up, process, and present these cancer-derived antigens on their surface via major histocompatibility complex class (MHC) I or MHC II molecules to naïve $\mathrm{T}$ cells in the lymph nodes, leading to priming and activation of T cells (Fig. 1(2)). Previously primed and activated tumor-infiltrating $\mathrm{CD} 8^{+}$cytotoxic $\mathrm{T}$ cells bind with their $\mathrm{T}$ cell receptor (TCR) to the cognate antigen, which is presented on the surface of cancer cells via MHC I molecules (Fig. 1(5)) [19]. Upon binding to the target antigen, effector $\mathrm{T}$ cells generate an antitumor immune response, culminating in tumor cell death.

At times, this immune response is misdirected and gives rise to the production of $\mathrm{CD} 8^{+}$cytotoxic $\mathrm{T}$ cells and autoantibodies that target the own nervous system (Fig. 1(6) + (7)) [19]. T cell-mediated PNSs are driven by intracellular antigens in the context of TCR binding (Fig. 1(2a)). Antibody-mediated PNSs derive from cell surface antigens that are presented by MHC II molecules on dendritic cells and recognized by $\mathrm{CD} 4^{+} \mathrm{T}$ helper cells. Interactions between activated $\mathrm{CD} 4^{+} \mathrm{T}$ helper cells and $\mathrm{B}$ cells result in the generation of memory $\mathrm{B}$ cells and antibody-secreting plasma cells (Fig. 1(2b)).

While many tumor cells are known to express neuronal antigens, only a minority of patients with such cancers develop PNSs [17]. Several studies suggest that genetic alterations during oncogenesis, resulting in the expression of highly immunogenic neoantigens by tumor cells, serve as the inciting event to trigger autoimmunity [20, 21]. In a study addressing the genetic characterization of ovarian carcinomas associated with paraneoplastic cerebellar degeneration and anti-Yo antibodies (Yo-PCD), somatic mutations in the Yo antigens CDR2 and CDR2L were found in $65 \%$ of the tumors. In $59 \%$ of Yo-PCD patients, gene amplification of the CDRL2 gene, encoding for the respective oncoprotein, was detected [20]. 
Further, anticancer immunity is not always necessarily accompanied by autoimmune neurological toxicity. In an experimental study, transgenic mice expressed the intracellular antigen $\beta$-galactosidase in both neurons and implanted tumor cells [22]. In this model, transfer of antigen-specific $\mathrm{T}$ cells caused $\mathrm{CD}^{+} \mathrm{T}$ cell-mediated tumor lysis without provoking autoimmune neurotoxicity [22].

\section{ICls-Boosters of Anticancer Immunity}

$\mathrm{T}$ cell activation is tightly regulated by counterbalancing co-stimulatory and co-inhibitory signals [23, 24]. The physiologic co-inhibitory immune checkpoints CTLA- 4 and PD-1 and its ligand PD-L1 are essential for maintaining immune self-tolerance [23, 24]. CTLA-4 is expressed on activated $\mathrm{CD}^{+}{ }^{+} \mathrm{T}$ helper cells, $\mathrm{CD} 8^{+}$cytotoxic $\mathrm{T}$ cells, and regulatory T cells. Binding of CTLA-4 to the ligands CD80 and CD86, which are found on professional APCs, inhibits T cell priming in the lymph nodes, and therefore intercepts $\mathrm{T}$ cell activation at an early step (Fig. 1(2a)) [23]. PD-1 is found on the surface of activated $\mathrm{T}$ cells, especially tumor-infiltrating $\mathrm{T}$ cells, B cells, macrophages, and natural killer cells, and binds to its ligand PD-L1, expressed on APCs and various tumor cells (Fig. 1(5)) [25]. Activation of the CTLA-4 and PD-1/PD-L1 pathways triggers a negative feedback mechanism to inhibit $\mathrm{T}$ cell functions which, as a consequence, prevents autoimmunity [23, 24].

Tumor cells can exploit and potentiate the CTLA-4 and PD-1/PD-L1 pathways leading to $\mathrm{T}$ cell anergy and $\mathrm{T}$ cell apoptosis. The circumvention of $\mathrm{T}$ cell-mediated antitumor immunity enables unchecked cancer proliferation [26]. Thus, augmenting the endogenous ability of $\mathrm{T}$ cells to mediate antitumor immune responses, resulting in tumor cell killing, has become a major focus in cancer therapeutics [19]. The manipulation of antigen-specific $\mathrm{T}$ cell responses to overcome the evasive mechanisms of cancer cells has led to the development of ICIs [27]. The armamentarium of ICIs consists of monoclonal antibodies targeting the coinhibitory molecules CTLA-4 (e.g., ipilimumab), PD-1 (e.g., nivolumab), and PD-L1 (e.g., atezolizumab) [4]. The therapeutic blockade of the CTLA-4 and PD-1/PD-L1 pathways promotes the activation of tumor-specific $\mathrm{T}$ cells resulting in tumor rejection. On the downside, the breakdown of immune tolerance is an undesired outcome of the therapeutic enhancement of T cell activity, manifesting as irAEs.

\section{ICI-Induced Immune Tolerance Breakdown in PNSs}

The exact pathomechanisms by which ICIs induce the diversity of irAEs are not fully elucidated [28]. In the case of PNSs, molecular mimicry due to sequence similarities between neuronal antigens and pathogen-derived antigens resulting in autoreactive $\mathrm{T}$ cells is proposed to be a driving pathogenic mechanism. Together with the ICI-induced augmentation of the immune system, the emergence of PNSs in patients with systemic cancer can be promoted. Findings in mouse models regarding the induction of paraneoplastic cerebellar degeneration upon ICI treatment support this hypothesis [29]. In this model, mice expressed a neo-selfantigen, which is shared by Purkinje cells and implanted breast tumor cells. Injection of antigen-specific lymphocytes limited tumor growth without causing neurological autoimmunity. Co-administration of an anti-CTLA-4 antibody increased antitumor immunity, however at the cost of neuroinflammation with histopathologic findings of $\mathrm{CD} 8^{+} \mathrm{T}$ cell-mediated Purkinje cell loss in the cerebellum and the consecutive development of paraneoplastic cerebellar degeneration [29].

Another possible pathogenic mechanism of neurologic irAEs is the modulation of humoral immunity with increased B cell-mediated antibody production [30]. This hypothesis is supported by findings in a mouse model, in which repeated injections of anti-CTLA-4 antibodies into mice induced pituitary antibodies [31]. Another study showed that patients with anti-CTLA-4-mediated hypophysitis developed pituitary antibodies that could have contributed to toxicity of anti-CTLA-4 therapy [32]. In addition to misdirected humoral immunity, autoreactive $\mathrm{T}$ cells may play an important role in ICI-mediated hypophysitis as endogenous pituitary cells were found to express CTLA-4 antigens [31].

\section{General Characteristics of PNSs}

While the clinical phenotypic presentations of PNSs are heterogeneous, these neurological disorders share some common features. PNSs are rare disorders, presenting in less than $1.0 \%$ of cancer patients, but clinically relevant because in up to $65 \%$ of patients they predate the diagnosis of an occult, often early-stage malignancy [17, 33]. Therefore, PNSs are often the first sign of a neoplasm. The most commonly recognized tumors in PNSs, accounting for about $73 \%$ of cases, include SCLC, breast cancer, ovarian cancer, NSCLC, and lymphoma [33]. The specific type and frequency of an underlying cancer depends on the neurological phenotype of the PNSs, demographic characteristics (age, presence of risk factors, e.g., smoking), and neuronal autoantibody type.

Certain neurological syndromes are more frequently associated with a paraneoplastic etiology and termed high-risk neurological phenotypes [15]. High-risk neurological phenotypes include the following diagnoses: encephalomyelitis, limbic encephalitis, rapidly progressive cerebellar syndrome, opsoclonus myoclonus syndrome (OMS), subacute sensory neuronopathy, gastrointestinal pseudo-obstruction, and Lambert-Eaton myasthenic syndrome (LEMS) [15]. Among these, rapidly progressive cerebellar syndrome and subacute 
sensory neuronopathy are the most common types of PNSs [33]. Clinical onset of PNSs is usually acute to subacute with a rapidly progressive course that can lead to disabling permanent neurological damage, or even death with a fatality rate of up to $27 \%$ [33]. Recognizing and identifying these disorders and their associated cancer allow timely initiation of oncologic treatment to prevent long-term neurological disability or death in patients with the potential of a good clinical outcome due to their limited stage disease [17]. A brief overview of the characteristic clinical presentation, cancer, and antibody association of high-risk PNSs phenotypes is summarized in Table 1 .

\section{Autoantibodies as Biomarkers in PNSs}

A mainstay in diagnosing PNSs is the detection of neuronal autoantibodies in the serum or cerebrospinal fluid (CSF) that are detectable in $82 \%$ of patients with PNSs [33]. These autoantibodies support an immune-mediated pathogenesis and can guide cancer screening measures as each type of detected antibody occurs with only a few tumor types.

These autoantibodies are usually associated with highly distinct and stereotypical neurological syndromes and can often reliably predict the paraneoplastic nature of the disorder and thus serve as important biomarkers for paraneoplastic autoimmunity [15]. Neuronal autoantibodies can be categorized into two main groups. Autoantibodies targeting intracellular nuclear or cytoplasmic neuronal proteins, previously referred to as onconeuronal antibodies, are highly indicative of an underlying malignancy and classified as high-risk antibodies for their frequent cancer association [15]. High-risk antibodies include Hu (also known as antineuronal nuclear antibody type 1 (ANNA-1)), Yo (also known as Purkinje cell cytoplasmic antibody type 1

Table 1 Clinical characteristics, antibody and cancer association of high-risk PNSs

\begin{tabular}{|c|c|c|c|c|}
\hline Syndrome & Clinical symptoms & Antibody association & Most common cancer association & References \\
\hline Encephalomyelitis & $\begin{array}{l}\text { Neurological dysfunction involving } \\
\text { multiple levels of the nervous } \\
\text { system, including the CNS, the } \\
\text { peripheral and autonomic nerv- } \\
\text { ous system }\end{array}$ & $\begin{array}{l}\mathrm{Hu}(\mathrm{ANNA}-1) \\
\text { CRMP5 (CV2) } \\
\text { MAP1B (PCA-2) }\end{array}$ & $\begin{array}{l}\text { SCLC } \\
\text { SCLC } \\
\text { SCLC, NSCLC, breast cancer }\end{array}$ & [34-36] \\
\hline Limbic encephalitis & $\begin{array}{l}\text { Short-term memory deficits, } \\
\text { insomnia, behavioral changes, } \\
\text { psychosis, seizures }\end{array}$ & $\begin{array}{l}\mathrm{Hu}(\mathrm{ANNA}-1) \\
\mathrm{Ma} 2 \\
\mathrm{AMPAR} \\
\text { GABA }_{\mathrm{B}} \mathrm{R} \\
\text { mGluR5 }^{\text {moR }}\end{array}$ & $\begin{array}{l}\text { SCLC } \\
\text { Testicular cancer, NSCLC } \\
\text { SCLC, thymoma } \\
\text { SCLC } \\
\text { Hodgkin lymphoma }\end{array}$ & {$[37-43]$} \\
\hline $\begin{array}{l}\text { Rapidly progressive cerebellar } \\
\text { syndrome }\end{array}$ & $\begin{array}{l}\text { Ataxia, diplopia, dysarthria, } \\
\text { nystagmus }\end{array}$ & $\begin{array}{l}\mathrm{Hu}(\text { ANNA-1) } \\
\text { Zic4 } \\
\text { Yo (PCA-1) } \\
\text { Tr (DNER) }\end{array}$ & $\begin{array}{l}\text { SCLC } \\
\text { SCLC } \\
\text { Ovarian and breast cancer } \\
\text { Hodgkin lymphoma }\end{array}$ & {$[44-47]$} \\
\hline OMS & $\begin{array}{l}\text { Involuntary, arrhythmic, multidi- } \\
\text { rectional chaotic saccadic eye } \\
\text { movements, myoclonus, cerebel- } \\
\text { lar syndrome, encephalopathy }\end{array}$ & $\begin{array}{l}\text { Ri (ANNA-2) (adults) } \\
\text { Glycine receptor } \\
\text { Seronegative (chil- } \\
\text { dren) }\end{array}$ & $\begin{array}{l}\text { Breast cancer } \\
\text { Lung cancer } \\
\text { Neuroblastoma }\end{array}$ & {$[48,49]$} \\
\hline Sensory neuronopathy & $\begin{array}{l}\text { Asymmetric hypesthesia, pain, } \\
\text { proprioceptive loss, typically } \\
\text { involving the arms, motor deficits } \\
\text { possible }\end{array}$ & $\begin{array}{l}\text { Hu (ANNA-1) } \\
\text { CRMP5 (CV2) } \\
\text { Amphiphysin }\end{array}$ & $\begin{array}{l}\text { SCLC } \\
\text { SCLC } \\
\text { SCLC, breast cancer }\end{array}$ & {$[50-52]$} \\
\hline $\begin{array}{l}\text { Gastrointestinal pseudo- } \\
\text { obstruction }\end{array}$ & $\begin{array}{l}\text { Abdominal pain, distension, } \\
\text { constipation, nausea, vomiting, } \\
\text { dysphagia }\end{array}$ & $\mathrm{Hu}$ (ANNA-1) & SCLC & {$[53]$} \\
\hline LEMS & $\begin{array}{l}\text { Proximal muscle weakness start- } \\
\text { ing in the limbs, progressing to } \\
\text { involve the upper extremity, facial } \\
\text { and ocular muscles, autonomic } \\
\text { dysfunction }\end{array}$ & $\begin{array}{l}\text { SOX1 (AGNA-1) } \\
\text { P/Q-type VGCC }\end{array}$ & $\begin{array}{l}\text { SCLC } \\
\text { SCLC }\end{array}$ & {$[54,55]$} \\
\hline
\end{tabular}

AGNA-1 anti-glial nuclear antibody type 1, AMPAR $\alpha$-amino-3-hydroxy-5-methyl-4-isoxazolepropionic acid receptor, ANNA antineuronal nuclear antibody, $C N S$ central nervous system, $C R M P 5$ collapsin response mediator protein 5, $C S F$ cerebrospinal fluid, $G A B A_{B} R$ GABA type B receptor, DNER delta and notch-like epidermal growth factor-related receptor, $L E M S$ Lambert-Eaton myasthenic syndrome, MAP1B microtubuleassociated protein $1 \mathrm{~B}, m G l u R 5$ metabotropic glutamate receptor 5, NSCLC non-small-cell lung cancer, OMS opsoclonus myoclonus syndrome, PNS paraneoplastic neurological syndrome, P/Q-type VGCC voltage-gated calcium channel, SCLC small-cell lung cancer, SOX1 SRYlike HMG box 1 
(PCA-1)), microtubule-associated protein 1B (MAP1B, also known as Purkinje cell cytoplasmic antibody type 2 (PCA2)), collapsing response mediator protein 5 (CRMP5, also known as CV2), Ri (also known as antineuronal nuclear antibody type 2 (ANNA-2)), Ma2, amphiphysin, SRY-Box 1 (SOX1, also known as anti-glial nuclear antibody (AGNA1)), $\operatorname{Tr}$ (also known as delta/notch-like epidermal growth factor-related receptor (DNER)), and Kelch-like protein 11 (KLHL11). Glutamate decarboxylase 65 (GAD65) antibodies are an exception to this rule as they are usually not paraneoplastic in origin despite directed against an intracellular antigen [56]. Previous studies have identified $\mathrm{Hu}$ and Yo as the most prevalent antibodies in PNSs with a frequency of $39 \%$ and $13 \%$, respectively $[33,39]$. Experimental studies found that autoantibodies directed against intracellular antigens are not directly pathogenic, because their target proteins are inaccessible to direct antibody binding [57]. Instead, postmortem studies in patients with PNSs and highrisk paraneoplastic antibodies suggest that neurodegeneration is mediated by $\mathrm{T}$ cell toxicity, based on the detection of granzyme- $\mathrm{B}^{+}$cytotoxic $\mathrm{T}$ cells in close proximity to neurons [58].

Autoantibodies targeting neuronal cell surface proteins have an intermediate risk for tumor association and can occur in the presence or absence of cancer [15]. Hence, the detection of these antibodies does not necessarily indicate a paraneoplastic origin. Autoantibodies with an intermediate risk for cancer association comprise N-methyl-D-aspartate receptor (NMDAR), $\alpha$-amino-3-hydroxy-5-methyl-4isoxazolepropionic acid receptor (AMPAR), GABA type $\mathrm{B}$ receptor $\left(\mathrm{GABA}_{\mathrm{B}} \mathrm{R}\right)$, metabotropic glutamate receptor 5 (mGluR5), contactin-associated protein-like 2 (CASPR2), and P/Q-type voltage-gated calcium channel (P/Q-type VGCC) [15]. These antibodies harbor the potential to directly unfold pathogenicity by binding to the target protein, resulting in the modulation of protein expression and function. As the target proteins are often ion channels, antibodies have been found to cause electrophysiologic changes, disturbances in synaptic transmission, and neuronal plasticity [59].

In general, patients with antibodies targeting intracellular neuronal structures are poorly responsive to immunosuppressive therapy. In these patients, histopathologic evidence demonstrates cytotoxic $\mathrm{T}$ cell-mediated neurodegeneration with severe neuronal cell loss and axonal dystrophy, which might explain the poor response of these disorders to immunomodulation [58]. Exceptions to this rule apply and include the recently identified anti-glial fibrillar acidic protein (GFAP)-associated meningoencephalomyelitis, which is frequently responsive to immunosuppression, even though GFAP targets intracellular proteins [60]. By contrast, the majority of patients with antibodies binding to surface-expressed CNS antigens shows profound neurologic improvement following immunosuppressive treatment aimed to remove the directly pathogenic antibodies or antibodyproducing cells [61-63].

\section{Autoantibody Profiles in ICI-Mediated PNSs}

Neuronal autoantibodies have been detected in $54.0 \%$ of patients with ICI-mediated neurological autoimmunity [12]. Most of these autoantibodies had intracellular antigenic specificity, including Ma2, GFAP, Hu, Ri, GAD65, SOX1, and CRMP5, which highlights their role as biomarkers of paraneoplastic neurologic autoimmunity [7, 12, 14, 16, 64]. Neurological dysfunction induced by autoantibodies targeting cell surface molecules, including CASPR2, NMDAR, LGI1, and P/Q-type VGCC, was also described, although less frequently [12, 64-66]. Recently discovered autoantibodies against the intracellular neuronal intermediate filament (NIF) or protein phosphodiesterase 10A (PDE10A) have been identified in the context of ICI treatment. NIF antibodies occurred in patients presenting with cerebellar ataxia and encephalopathy following anti-PD-1 therapy [67]. Patients harboring PDE10A antibodies developed hyperkinetic movement disorders as a paraneoplastic phenomenon after the onset of ICI therapy [68]. Novel autoantibodies, including those with unknown molecular specificity, discovered in neurological irAEs, are not detectable with commercially available antigen-specific cell-based assays. Alternatively, an unbiased neuronal autoantibody testing methodology is preferred. In particular, indirect immunofluorescence on rodent brain tissue, known as tissue-based assay, can assess for the presence of novel autoantibodies [69]. As neuronal autoantibodies are frequently encountered in ICI-mediated neurological autoimmunity, autoantibody testing is recommended to assist in diagnosing these disorders and guiding therapeutic decisions for a favorable patient outcome.

\section{Clinical Characteristics of PNSs in the Setting of ICI Treatment}

Some neurologic irAEs fulfill the criteria for a PNS with the typical (i) clinical syndromic manifestation, (ii) tumor association, and (iii) antibody association [15]. In previous studies, most patients with ICI-mediated PNSs and detectable neuronal autoantibodies had CNS involvement and commonly presented with the stereotypical syndromic manifestation associated with the neuronal antibody [13, 14]. This observation suggests that ICIs may be able to unleash PNSs.

While in spontaneous PNSs neurologic symptoms typically precede the diagnosis of an early-stage cancer, ICImediated PNSs develop shortly after the initiation of cancer immunotherapy in patients that were previously diagnosed 
with an advanced stage malignancy $[33,70]$. ICIs can also induce PNSs in non-neuroendocrine malignancies that are not typically linked to paraneoplastic conditions, such as melanoma, non-SCLC, or renal cell carcinoma [12]. Cancer immunoediting resulting in the expression of altered neoantigens has been observed in patients with melanoma when subjected to ICI therapy and might be contributing to increased immunogenicity in cancers not classically recognized for paraneoplastic autoimmunity [71, 72].

Potentially life-threatening PNSs include paraneoplastic encephalitis or myasthenic syndromes [10, 73]. Especially cases with anti-Ma2-associated encephalitis presented with severe neurologic deterioration irresponsive to immunosuppressive therapies and were often fatal $[16,73]$. In ICIrelated myasthenic syndromes, mortality rates are estimated at $30.4 \%$ [74]. The risk for myasthenic crisis and comorbid myositis and myocarditis is higher compared to idiopathic myasthenia gravis [10]. Acetylcholine receptor (AChR) antibodies were detected in about $70 \%$ of ICI-associated myasthenic syndromes [10].

Caution is warranted in patients with pre-existent evidence of seropositive PNSs. ICIs can worsen pre-existent PNSs resulting in potentially irreversible neurological dysfunction or even death $[12,73]$. Notably, patients with a prior history of paraneoplastic encephalitis or rapidly progressive cerebellar syndrome with seropositivity for neuronal autoantibodies, such as P/Q-type VGCG, amphiphysin, ANNA-1, and CRMP5, presented with severe progression of their neurological disorder without improvement following immunosuppression [12, 73].

This finding underscores the importance of a careful risk-benefit evaluation before initiating ICIs in patients at high risk for severe neurotoxicity. Determining a baseline serologic profile of patients with typical paraneoplastic cancers may aid in predicting the risk for adverse events and guide therapeutic decisions to improve patient outcome. However, prospective studies need to evaluate whether patients with cancers known for their paraneoplastic association and detectable neuronal autoantibodies are at higher risk for developing PNSs in the scenario of immunotherapy.

In the following section, we provide a brief overview of the clinical features associated with ICI-induced PNSs. A full review of the clinical characteristics of PNSs is beyond the scope of this review and has been already reported in detail previously [18].

\section{Encephalomyelitis}

Paraneoplastic encephalomyelitis is characterized by multifocal involvement of the nervous system, including the CNS, the peripheral nervous system, and the autonomic nervous system. The predominant cancer is SCLC and the most commonly detected autoantibodies are Hu and CRMP5
$[34,35]$. The diagnosis of paraneoplastic encephalomyelitis is challenging due to multifocal neurological signs. Brain and spine MRI play a pivotal role to evaluate diffuse brain lesions that indicate disseminated encephalomyelitis. Electrodiagnostic studies can show peripheral nerve involvement. Most patients with anti-Hu-associated encephalomyelitis progress despite immunotherapy with or without concurrent antineoplastic treatment leading to neurological disability or death [34].

Encephalomyelitis linked to ICI treatment has been rarely described. Worsening of preexisting anti-Hu- and antiCRMP5-associated encephalomyelitis following nivolumab therapy for SCLC has been observed [12]. Neurologic outcome was poor even after ICI discontinuation, intravenous (IV) methylprednisolone, intravenous immunoglobulins (IVIGs), plasmapheresis, and cyclophosphamide. This case exemplarily demonstrates the risk of severe neurologic progression in patients with pre-existent seropositive PNSs and urges caution for applying ICIs in this setting.

\section{Limbic Encephalitis and Beyond}

Limbic encephalitis is one of the most common PNSs affecting the CNS. Both paraneoplastic and non-paraneoplastic autoimmune forms of limbic encephalitis exist with similar clinical presentations [75]. The likelihood of cancer association depends on the detected neuronal autoantibody, and the spectrum of associated autoantibodies in limbic encephalitis is wide. While $\mathrm{Hu}, \mathrm{Ma} 2$, AMPAR, and $\mathrm{GABA}_{\mathrm{B}} \mathrm{R}$ autoantibodies are frequently associated with cancers, CASPR2 and LGI1 usually manifest as non-paraneoplastic limbic encephalitis $[37,38,76]$. Typical underlying malignancies are SCLC, testicular germ cell cancer, and Hodgkin lymphoma [39]. A hallmark of clinical presentation is shortterm memory dysfunction. Patients further present with insomnia, behavioral changes, psychiatric symptoms, and sometimes seizures [39]. In anti-Ma2-associated encephalitis, additional diencephalic involvement has been observed, clinically manifesting as weight gain, narcolepsy, and hyperphagia [16]. MRI T2/FLAIR hyperintensities in the uni- or bilateral mesiotemporal lobes further suggest limbic system involvement [77]. CSF analysis typically reveals inflammatory changes with lymphocytic pleocytosis [39].

Paraneoplastic limbic encephalitis related to ICI treatment has been observed in patients with SCLC, but also in tumors not typically associated with PNSs, including melanoma and myxoid chondrosarcoma [18, 65, 78-81]. Neuronal autoantibodies including CASPR2, GAD65, Ma2, Hu, SOX1, and P/Q-type VGCC, as well as seronegative cases, have been reported in ICI-mediated limbic encephalitis [7, 65, 78, 80, 82, 83]. Except for anti-SOX1 and P/Q-type VGCC antibodies, which are usually associated with LEMS, the remaining autoantibodies resemble those that are frequently 
present in spontaneous paraneoplastic and autoimmune limbic encephalitis. Overall, most cases of ICI-induced limbic encephalitis demonstrated marked neurological improvement or resolution with ICI discontinuation and steroids as first-line therapy, except for anti-Ma2 positive cases that are associated with a poor neurologic outcome [64]. For worsening symptoms, second-line therapy with IVIGs or rituximab can be beneficial $[12,78,79]$. Natalizumab has also been successfully used in this setting [83].

Autoimmune encephalitis related to NMDAR autoantibodies is considered an intermediate-risk paraneoplastic phenotype as cancer association depends on sex and age. Anti-NMDAR encephalitis presents with prominent psychiatric symptoms, memory deficits, orofacial dyskinesia, seizures, and rapid deterioration of level of consciousness, at times requiring ventilatory support. These symptoms often develop shortly after a prodromal episode with viral-like illness [84]. The presentation of these symptoms in young women should promptly warrant cancer screening for ovarian teratoma, as up to $60 \%$ of women harvest these tumors [85]. Only a few cases of anti-NMDAR encephalitis have been reported in the context of ICI therapy in patients with cancers not typically associated with these PNSs, including melanoma, Merkel cell carcinoma, and endometrial adenocarcinoma [12, 78, 86]. Previous studies have revealed that malignant melanomas harbor somatic mutations in the gene GRIN2A which encodes for the NMDAR subunit NR2A, resulting in loss of NMDAR complex formation, suggesting that altered expression of neuronal antigens in melanoma cells in conjunction with immune stimulation with ICIs might have triggered the production of pathogenic autoantibodies [87, 88].

The lack of patients with ovarian carcinoma might be explained by the fact that ICIs are currently not approved for the treatment of ovarian cancer. Previous studies have observed neurologic improvement in two cases of ICImediated anti-NMDAR encephalitis following rituximab as firstor second-line therapy $[12,78]$, whereas IV methylprednisolone and plasmapheresis were ineffective [86].

\section{Rapidly Progressive Cerebellar Syndrome}

Rapidly progressive cerebellar syndrome manifests with rapidly evolving ataxia, diplopia, dysarthria, and nystagmus [89-91]. Paraneoplastic cerebellar dysfunction is mostly associated with SCLC and Hu or Zic4 antibodies, gynecological and breast cancer with Yo antibodies, and Hodgkin lymphoma with DNER or mGluR1 antibodies [92]. MRI abnormalities are absent in most patients. In some cases, mild cerebellar atrophy, cerebellar edema, and diffuse T2/FLAIR hyperintensities in the cerebellar cortex have been observed [12, 64, 89]. CSF abnormalities comprise inflammatory changes with mild lymphocytic pleocytosis, protein elevation, and in some cases oligoclonal bands [64].

In the context of ICI treatment, rapidly progressive cerebellar syndrome developed in patients with underlying NSCLC, SCLC, bladder cancer, Hodgkin lymphoma, and melanoma [64, 89-91]. Neuronal autoantibodies including $\mathrm{Hu}$, NIF, CRMP5, amphiphysin, and P/Q-type VGCC, as well as antibodies with atypical neuropil staining, along with seronegative cases, have been reported in this setting [64, 89-91]. Marked clinical improvement was observed especially in seronegative cases of rapidly progressive cerebellar syndrome following ICI withdrawal and steroid therapy. However, anti-Hu-associated cerebellar dysfunction and additional administration of IVIG only provided moderate resolution [12, 64].

\section{Opsoclonus Myoclonus Syndrome}

OMS is characterized by involuntary, arrhythmic, multidirectional chaotic saccadic eye movements and is commonly accompanied by myoclonus and a cerebellar syndrome (ataxia, dysarthria) [48, 93]. In children, OMS is strongly associated with the presence of neuroblastoma, whereas in adults the most common underlying tumors are breast cancer associated with $\mathrm{Ri}$ antibodies and lung cancer associated with glycine receptor antibodies [49]. MRI and CSF findings are often unremarkable. To date, one case of OMS has been reported in a patient with mesothelioma following antiCTLA-4 and anti-PD-1 combination therapy [94]. Neurologic symptoms resolved with high-dose methylprednisolone along with IVIGs.

\section{Sensory Neuronopathy}

Sensory neuronopathy (SN) presents with subacute onset of asymmetric hypesthesia, severe pain, and loss of proprioception, typically involving the arms, and sometimes occurs with motor deficits [51]. Electrodiagnostic studies reveal involvement of the dorsal root ganglia of sensory neurons. These syndromes are frequently associated with SCLC and Hu or CRMP5 antibodies [51]. SN has been reported in two patients with melanoma and SCLC following ICI therapy $[13,95]$. In the latter, anti-Hu antibodies were detected. In both patients, neurological symptoms improved following ICI discontinuation and steroid therapy.

\section{Lambert-Eaton Myasthenic Syndrome}

LEMS is a neuromuscular junction disorder presenting with proximal muscle weakness starting in the limbs, progressing to involve the upper extremity, facial, and ocular muscles. Progressive muscle weakness is often accompanied by autonomic dysfunction and generalized fatigue. Pathogenic 
antibodies directed against the presynaptic P/Q-type VGCC are detected in up to $90 \%$ of patients with either paraneoplastic or non-paraneoplastic LEMS, while SOX1 antibodies are highly indicative of an underlying SCLC $[54,55]$. Repetitive nerve stimulation demonstrating an increase in the compound muscle action potential (increment) is supportive of LEMS. While myasthenic syndromes have been increasingly recognized as severe manifestations of neurologic irAEs, occurring in about $0.1-0.2 \%$ of patients receiving ICIs, only a few cases of ICI-related LEMS have been described [66, 96-98]. All cases were positive for P/Q-type VGCC autoantibodies and the underlying tumors were SCLC and NSCLC. Marked clinical improvement was only achieved in one case with IVIGs and 3,4-diaminopyrimidine [98], while in the two remaining patients rituximab as second-line therapy [97] and steroids as first-line therapy did not resolve neurological disability [66].

\section{Diagnostic Approach}

Recognizing PNSs related to ICI therapy is often challenging, given their rarity and broad differential diagnoses. Important alternative causes include infections, metabolic disorders, tumor progression, or complications due to other therapeutic modalities.

New onset of acute or subacute neurologic symptoms in patients recently commencing ICI treatment raises suspicion for a neurologic irAE. All patients should undergo a thorough neurologic evaluation to localize the region of involvement. In patients with suspected paraneoplastic CNS disorder, MRI of the brain and spine can provide imaging evidence to the underlying pathology and rule out metastatic disease of the brain or leptomeninges. CSF analysis should include infectious studies to exclude bacterial, viral, and fungal meningitis and cytopathology to search for clues of leptomeningeal carcinomatosis [99]. Testing for neuronal autoantibodies in the CSF and serum is recommended, as they are frequently positive in irAEs affecting the CNS [12]. In patients with suspected peripheral nervous system involvement, electrodiagnostic findings from electromyography and nerve conduction studies can indicate an immune-related neuropathy, such as non-lengthdependent polyradiculoneuropathy or cranial neuropathy [95]. Immune-related neuropathies have to be distinguished from toxic neuropathies related to chemotherapy, which commonly present as symmetric length-dependent sensory polyneuropathy. In addition, neuronal autoantibody panels in the CSF and serum may reveal paraneoplastic antibodies, such as $\mathrm{Hu}$ or CASPR2.

For suspected neuromuscular disorders, including myasthenia gravis and LEMS, antibodies against AChR, musclespecific tyrosine kinase (MuSK), titin, SOX1, and P/Q-type
VGCC should be determined. Repetitive nerve stimulation revealing decrement or increment is supportive of myasthenia gravis and LEMS, respectively.

An interdisciplinary team consisting of oncologists and neurologists is required to timely diagnose ICI-related PNSs and initiate appropriate therapeutic measures to substantially reduce patient morbidity and mortality.

\section{General Management Recommendations of ICI-Induced PNSs}

Multinational and multidisciplinary organizations, including the American Society of Clinical Oncology (ASCO), the European Society for Medical Oncology (ESMO), the Society for Immunotherapy of Cancer (SITC), and the National Comprehensive Cancer Network (NCCN), have issued comprehensive outlines for the management of irAEs [99-102]. The specific therapeutic guidelines depend on the involved organ system and the severity of the toxicity. The severity of irAEs is graded according to the National Cancer Institute's Common Terminology Criteria for Adverse Events (CTCAE) into grades 1-5, which in increasing order corresponds to mild (1), moderate (2), severe (3), life-threatening (4), and death due to immunotherapy (5) [103].

Patients with neurologic irAEs should be referred to neurologists with expertise in neuro-oncology. PNSs related to ICI treatment are generally considered grade $>2$ neurotoxicities due to the severe clinical course that almost always leads to disabling neurological sequalae. The cornerstones of first-line management are the discontinuation of ICIs and corticosteroid treatment as most patients improve with these therapeutic measures $[5,7,8,12]$. Current guidelines advise against the reintroduction of ICI therapy in severe neurologic irAEs [99].

Steroids are administered as either oral prednisone $(1 \mathrm{mg} /$ $\mathrm{kg}$ daily over 4-6 weeks with a slow steroid taper) or as intravenous methylprednisolone (1-4 mg/kg per day or pulse dose with $1000 \mathrm{mg}$ daily for 3-5 days). It has been promising that no clear evidence of systemic steroid use negatively impacting overall survival in oncologic patients with irAEs has been established [104, 105].

In anticipated prolonged and steroid-refractory cases, escalation of immunosuppressive therapy is indicated to prevent permanent neurological dysfunction. IVIGs are currently recommended for Guillain-Barré syndrome, myasthenia gravis, severe or progressive encephalitis, and transverse myelitis following ICI therapy [106]. Several studies have also demonstrated neurological improvement with IVIGs in patients with ICI-mediated PNSs, such as limbic encephalitis $[7,10,12,13]$. IVIGs are typically administered with standard protocol at $2 \mathrm{~g} / \mathrm{kg}$ over the course of 5 days. Plasmapheresis with 5-7 cycles every 
other day has been effective in antibody-mediated neurotoxicities, including myasthenia gravis or autoimmune encephalitis [99].

More aggressive immunosuppressive options may be needed in certain cases and should be guided by the pathogenesis ( $\mathrm{T}$ cell-mediated versus antibody-mediated) of the PNSs based on the detected autoantibody profile. PNSs associated with antibodies against intracellular antigens are mainly mediated by cytotoxic $\mathrm{T}$ cells and rarely improve with treatment. Patients with directly pathogenic neuronal autoantibodies targeting surface antigens commonly respond to immunotherapies that deplete diseasedriving antibodies [61-63]. In the following section, we discuss emerging and potential novel immunotherapeutic concepts of ICI-mediated PNSs and focus on therapeutic antibody-selective immunotherapies. Figure 1 depicts therapeutic options according to the proposed mechanisms of ICI-induced PNSs.

\section{Rituximab}

B cell-depleting therapies are proposed to exert their effects by diminishing dysfunctional autoantibody production and by modulating autoreactive pro-inflammatory $\mathrm{T}$ cell activity $[107,108]$. In particular, anti-CD20 monoclonal antibodies, such as rituximab, have demonstrated to be highly effective in autoimmune neurological disorders [109]. Rituximab is a monoclonal chimeric antibody targeting the transmembrane protein $\mathrm{CD} 20$, which is primarily found on the surface of premature and differentiated $\mathrm{B}$ cells, but is absent on mature plasma cells (Fig. 1(2b)). Binding of rituximab to the cell surface protein $\mathrm{CD} 20$ induces a selective depletion of circulating $\mathrm{CD} 19^{+}$and $\mathrm{CD} 20^{+} \mathrm{B}$ cells, except for the terminally differentiated plasma cells [110]. Anecdotal case reports and small case series have reported beneficial effects of second-line rituximab therapy in refractory ICI-related neurotoxicities, including anti-GAD65-associated limbic encephalitis [111], seronegative encephalitis [112], or antiNMDAR encephalitis $[12,78]$. Rituximab was commonly administered at $375 \mathrm{mg} / \mathrm{m}^{2}$ weekly over 4 weeks [99]. The absence of detectable autoantibodies is no reason to discard rituximab therapy. Previous studies demonstrated that the efficacy of rituximab was independent from antibody status in patients with autoimmune limbic encephalitis and thus comparable between patients with autoantibodies that were undetectable, directly pathogenic or directed against intracellular antigens [113]. Further CD20-targeting monoclonal antibodies, such as ofatumumab, obinutuzumab, and the humanized equivalent ocrelizumab, might be considered alternatives for rituximab, given their similar efficacy and safety profile, although there is a paucity of evidence for their application in this setting [108].

\section{Natalizumab}

Natalizumab is a humanized monoclonal antibody that selectively targets $\alpha_{4}$-integrin on the surface of lymphocytes, which binds to vascular cell adhesion molecule-1 (VCAM1) expressed on endothelial cells of the blood-brain barrier (BBB) (Fig. 1(6)). Blocking of $\alpha_{4}$-integrin prevents endothelial transmigration of activated $\mathrm{T}$ lymphocytes across the BBB into the CNS [114]. Natalizumab can therefore limit CNS inflammation without affecting systemic immune effects in other compartments. Natalizumab was successfully applied in a patient with ICI-mediated anti-Hu-associated limbic encephalitis, where neuronal damage is suggested to be the result of pathogenic T cell-mediated immunity [58, 83]. This finding supports the use of natalizumab in ICImediated paraneoplastic encephalitis as the prevention of pathogenic $\mathrm{T}$ cell infiltration across the BBB can block the inflammatory cascade within the CNS to start.

\section{Cyclophosphamide}

Active metabolites of cyclophosphamide are alkylating agents that form cross-links within DNA strands leading to profound effects on $\mathrm{T}$ cell function and thereby decreasing the immune response (Fig. 1(4)) [115]. As cyclophosphamide preferentially targets $\mathrm{T}$ lymphocytes, it is often used in PNSs mediated by a cytotoxic T cell response [116, 117]. Improvement in neurologic symptoms following cyclophosphamide as second-line therapy has been observed in ICI-mediated PNSs with a classic paraneoplastic association, including anti-Hu and anti-CRMP5 antibody-positive cerebellar ataxia with peripheral neuropathy and encephalomyelitis, anti-Hu and striational antibody-positive limbic encephalitis with cerebellar ataxia and cranial neuropathy, and anti-CRMP5-positive progressive myelopathy $[12,118]$.

\section{Potential Future Biologics Therapies}

\section{Anti-CD19 Therapy}

Inebilizumab is a humanized monoclonal antibody targeting the transmembrane protein CD19, which is widely expressed on all B lineage cells, including plasma blasts and plasma cells (Fig. 1(2b)) [119]. Treatment with inebilizumab induces a depletion of $\mathrm{CD} 19^{+} \mathrm{B}$ cells via antibodydependent cellular cytotoxicity (ADCC) and may target a larger proportion of pathogenic B cells compared to the CD20-depleting agent rituximab [120]. The phase II/III clinical trial N-MOmentum reported reduced relapse rates in NMOSD patients treated with inebilizumab, which is currently approved for the treatment of aquaporin-4 antibody (AQP4)-positive NMOSD in adults [121]. Ongoing clinical 
trials investigate the use of inebilizumab for the therapy of myasthenia gravis. The results from the N-MOmentum trial suggest that CD19-depleting agents have the potential to provide benefit in antibody-mediated diseases, which may extend into the setting of PNSs, induced by humoral autoimmunity.

\section{Anti-CD52 Therapy}

Alemtuzumab is a humanized monoclonal antibody targeting the glycoprotein CD52, which is predominantly expressed on the surface of mature B and T cells (Fig. 1(2)), but is also found at lower levels on cells of the innate immune system, including eosinophils, monocytes, macrophages, neutrophils, and natural killer cells [122]. Treatment with alemtuzumab induces depletion and reconstitution of circulating $\mathrm{CD}_{2} 2^{+} \mathrm{B}$ and $\mathrm{T}$ lymphocytes, resulting in sustained changes of the adaptive immunity, which is thought to contribute to the clinical benefits in autoimmune disorders [123]. Alemtuzumab is currently approved for the therapy of relapsing-remitting multiple sclerosis [124]. Individual case reports and small case series describe successful application of alemtuzumab in the setting of seropositive paraneoplastic disorders, including cancer-associated retinopathy (CAR) with detectable CAR autoantibodies [125] and desmoglein 3- and desmoplakin I- and II-positive paraneoplastic pemphigus (PNP) [126]. The immunopathologic mechanisms underlying PNP involve activated autoreactive $\mathrm{T}$ cells that promote both humoral and cell-mediated immunity, and in CAR, the majority of autoantibodies are directed against intracellular antigens [127]. These experiences might translate into $\mathrm{T}$ cell-mediated paraneoplastic neurological disorders. However, a pitfall of alemtuzumab therapy is the development of secondary antibody-mediated autoimmune disorders (most commonly thyroid disease), which is proposed to be driven by increased interleukin (IL) 21 levels, mediating the expansion of self-antigen-responsive $\mathrm{T}$ cells $[128,129]$.

\section{Anti-neonatal Fc Receptor Therapy}

Novel immunotherapeutic approaches are evolving that aim at reducing pathogenic autoantibodies by inhibiting the neonatal $\mathrm{Fc}$ receptor $(\mathrm{FcRn})$ for immunoglobulin $\mathrm{G}(\mathrm{IgG})$. The FcRn binds to IgG or albumin and thereby prevents their lysosomal degradation in endothelial cells (Fig. 1(8)). Thus, the FcRn contributes to protective humoral immunity by maintaining IgG and albumin homeostasis [130, 131]. Phase II clinical trials have reported reduced pathogenic anti-AChR IgG concentrations in patients with myasthenia gravis receiving the monoclonal therapeutic antibodies efgartigimod or rozanolixizumab that both target the FcRn $[132,133]$. Ongoing phase III clinical studies are assessing the efficacy of these novel therapeutics. Exploratory results suggest that anti-FcRn therapies have the potential to provide clinical benefit in patients with myasthenia gravis. Future therapeutic implications of anti-FcRn may extend beyond de novo autoimmune disorders into the context of PNSs.

\section{Anti-interleukin-6 Therapy}

IL-6 is one of the main cytokines that at high levels can promote inflammatory processes and is involved in the pathogenesis of several autoimmune diseases, including neuromyelitis optica spectrum disorder (NMOSD) [134]. Inhibition of IL-6 signaling with the monoclonal antibodies tocilizumab or satralizumab that target the IL-6 receptor (IL-6R) (Fig. 1(3)) suppresses pro-inflammatory cascades and has shown to ameliorate neurologic symptoms and relapse rates in patients with NMOSD refractory to multiple immunosuppressive therapies [135-137]. Tocilizumab has improved neurological symptoms in a patient with ICI-related steroidrefractory transverse myelitis with high levels of IL-6 in the CSF [138] and demonstrated efficacy in patients with ICI-mediated cerebritis [139]. Satralizumab is a modified anti-IL-6R antibody with a pH-dependent antibody-antigen binding which prolongs the elimination half-life of the drug and has been recently FDA-approved for the treatment of NMOSD [140]. Until now, no cases of ICI-mediated PNSs treated with satralizumab have been reported. Emerging evidence indicates that high IL-6 levels correlate with disease activity and CNS inflammation, while a decrease in IL-6 levels reflects treatment response in NMOSD [135, 141]. Measuring IL-6 levels in the serum or CSF in ICI-mediated CNS inflammation can help to determine patients that might benefit from therapeutic anti-IL-6 blockade.

\section{Anti-C5 Therapy}

The C5 inhibitors eculizumab or ravulizumab are humanized monoclonal antibodies that directly bind to the terminal complement component $\mathrm{C} 5$, inhibiting enzymatic cleavage to the fragments C5a and C5b (Fig. 1(7)). As a result, C5a-mediated chemotaxis of inflammatory cells and C5b-mediated formation of the terminal membrane attack complex (MAC) are inhibited, preventing complementinduced inflammation and cytolysis, respectively [142]. Preclinical studies of AChR IgG-positive myasthenia gravis and AQP4-IgG-positive NMOSD have demonstrated complement-mediated neuronal damage, which was absent with the administration of complement inhibitors [143-145]. Based on the results of the REGAIN and PREVENT studies, eculizumab is now FDA-approved for refractory AChR IgGpositive myasthenia gravis and AQP4-IgG-positive relapsing NMOSD [146, 147]. Ravulizumab has been re-engineered from eculizumab to extend its half-life and is currently 
approved for the treatment of paroxysmal nocturnal hemoglobinuria and atypical hemolytic uremic syndrome [148, 149]. In the current management guidelines, neither eculizumab nor ravulizumab is listed as therapeutic options for neurological irAEs. Future research needs to identify ICIinduced PNSs, in which complement-mediated membrane damage and inflammation plays a pivotal role in the pathogenesis of the disease to expand the use of anti-C5 inhibitors beyond de novo autoimmune neurological disorders.

\section{Conclusion}

Immune checkpoint inhibitors have become a crucial pillar of cancer therapies, yet they can be complicated by lifethreatening PNSs that bear the potential for severe and permanent disability. Timely diagnosis and improved treatment algorithms of ICI-triggered PNSs are invaluable for a favorable patient outcome and require knowledge of the diverse spectrum of clinical presentations. A thorough differential work-up is necessary to distinguish these neurotoxic effects from complications of the underlying malignancy or complications of other treatment modalities. Testing for neuronal autoantibodies in the serum and CSF is recommended in suspected cases and, if present, can indicate an enhanced immune-mediated process. Further, the detected autoantibody profile (intracellular versus synaptic antibodies) can guide therapeutic measures. Novel targeted therapeutic approaches with antibody-selective immunotherapies should be implemented in PNSs to avoid serious adverse effects that are commonly seen with established chronic immunosuppressants. In light of the broadened indications for ICIs, especially in cancers strongly associated with PNSs, improved diagnostic and therapeutic algorithms for ICI-triggered PNSs are invaluable to reduce patient morbidity and mortality. Future research is needed to determine biomarkers to identify patients at risk for ICI-induced PNSs.

Glossary AChR: Acetylcholine receptor; ADCC: Antibody-dependent cellular cytotoxicity; AGNA-1: Anti-glial nuclear antibody type 1; AMPAR: $\alpha$-Amino-3-hydroxy-5-methyl-4-isoxazolepropionic acid receptor; ANNA: Antineuronal nuclear antibody; APC: Antigenpresenting cells; bbb: Blood-brain barrier; CAR: Cancer-associated retinopathy; CASPR2: Contactin-associated protein-like 2; CDC: Complement-dependent cytotoxicity; CNS: Central nervous system; CRMP5: Collapsin response mediator protein 5; CSF: Cerebrospinal fluid; CTCAE: Common Terminology Criteria for Adverse Events; CTLA-4: Cytotoxic T lymphocyte associated antigen 4; DNER: Delta and notch-like epidermal growth factor-related receptor; FcRn: Neonatal $\mathrm{Fc}$ receptor; $\mathrm{GABA}_{\mathrm{B}} \mathrm{R}$ : GABA type B receptor; GFAP: Glial fibrillar acidic protein; ICI: Immune checkpoint inhibitor; IL: Interleukin; Ig: Immunoglobulin; IrAE: Immune-related adverse event; IV: Intravenous; IVIG: Intravenous immunoglobulin; KLHL11: Kelch-like protein 11; LEMS: Lambert-Eaton myasthenic syndrome; LGI1: Leucine-rich glioma-inactivated protein 1; MAP1B: Microtubule-associated protein 1B; mGluR5: Metabotropic glutamate receptor 5; MHC: Major histocompatibility complex class I/II; MRI: Magnetic resonance imaging; MuSK: Muscle-specific tyrosine kinase; NIF: Neuronal intermediate filament; NK: Natural killer cell; NMDAR: N-methyl-D-aspartate receptor; NMOSD: Neuromyelitis optica spectrum disorder; NSCLC: Non-smallcell lung cancer; GAD65: Glutamate decarboxylase 65; OMS: Opsoclonus myoclonus syndrome; PCA: Purkinje cell cytoplasmic antibody; PCD: Paraneoplastic cerebellar degeneration; PD-1: Programmed cell death protein 1 receptor; PDE10A: Protein phosphodiesterase 10A; PDL1: Programmed cell death protein ligand 1; PNP: Paraneoplastic pemphigus; PNS: Paraneoplastic neurological syndrome; P/Q-type VGCC : P/Q-type voltage-gated calcium channel; SCLC: Small-cell lung cancer; SOX1: SRY-like HMG box 1; VCAM-1: Vascular cell adhesion molecule-1

Supplementary Information The online version contains supplementary material available at https://doi.org/10.1007/s13311-022-01184-0.

Required Author Forms 27 provided by the authors are available with the online version of this article.

Author Contribution S.L.D. and H.P contributed to the conception and design of the study, and drafted the manuscript. All authors critically revised, read, and approved the final manuscript.

Funding Open Access funding enabled and organized by Projekt DEAL.

\section{Declarations}

Conflict of Interest The authors declare no competing interests.

Open Access This article is licensed under a Creative Commons Attribution 4.0 International License, which permits use, sharing, adaptation, distribution and reproduction in any medium or format, as long as you give appropriate credit to the original author(s) and the source, provide a link to the Creative Commons licence, and indicate if changes were made. The images or other third party material in this article are included in the article's Creative Commons licence, unless indicated otherwise in a credit line to the material. If material is not included in the article's Creative Commons licence and your intended use is not permitted by statutory regulation or exceeds the permitted use, you will need to obtain permission directly from the copyright holder. To view a copy of this licence, visit http://creativecommons.org/licenses/by/4.0/.

\section{References}

1. Larkin J, Chiarion-Sileni V, Gonzalez R, Grob JJ, Cowey CL, Lao $\mathrm{CD}$, et al. Combined nivolumab and ipilimumab or monotherapy in untreated melanoma. N Engl J Med. 2015;373(1):23-34.

2. Reck M, Rodríguez-Abreu D, Robinson AG, Hui R, Csôszi T, Fülöp A, et al. Pembrolizumab versus chemotherapy for PD-L1-positive non-small-cell lung cancer. N Engl J Med. 2016;375(19):1823-33.

3. Horn L, Mansfield AS, Szczęsna A, Havel L, Krzakowski M, Hochmair MJ, et al. First-line atezolizumab plus chemotherapy in extensive-stage small-cell lung cancer. $\mathrm{N}$ Engl J Med. 2018;379(23):2220-9.

4. Gubin MM, Zhang X, Schuster H, Caron E, Ward JP, Noguchi $\mathrm{T}$, et al. Checkpoint blockade cancer immunotherapy targets tumour-specific mutant antigens. Nature. 2014;515(7528):577-81. 
5. Kao JC, Liao B, Markovic SN, Klein CJ, Naddaf E, Staff NP, et al. Neurological complications associated with anti-programmed death 1 (PD-1) antibodies. JAMA Neurol. 2017;74(10):1216-22.

6. Spain L, Walls G, Julve M, O’Meara K, Schmid T, Kalaitzaki E, et al. Neurotoxicity from immune-checkpoint inhibition in the treatment of melanoma: a single centre experience and review of the literature. Ann Oncol. 2017;28(2):377-85.

7. Duong SL, Barbiero FJ, Nowak RJ, Baehring JM. Neurotoxicities associated with immune checkpoint inhibitor therapy. J NeuroOncol. 2021.

8. Cuzzubbo S, Javeri F, Tissier M, Roumi A, Barlog C, Doridam J, et al. Neurological adverse events associated with immune checkpoint inhibitors: Review of the literature. Eur J Cancer. 2017;73:1-8.

9. Zimmer L, Goldinger SM, Hofmann L, Loquai C, Ugurel S, Thomas I, et al. Neurological, respiratory, musculoskeletal, cardiac and ocular side-effects of anti-PD-1 therapy. Eur J Cancer. 2016;60:210-25.

10. Suzuki S, Ishikawa N, Konoeda F, Seki N, Fukushima S, Takahashi $\mathrm{K}$, et al. Nivolumab-related myasthenia gravis with myositis and myocarditis in Japan. Neurology. 2017;89(11):1127-34.

11. Wang DY, Salem J-E, Cohen JV, Chandra S, Menzer C, Ye F, et al. Fatal toxic effects associated with immune checkpoint inhibitors: a systematic review and meta-analysis. JAMA Oncol. 2018;4(12):1721-8.

12. Sechi E, Markovic SN, McKeon A, Dubey D, Liewluck T, Lennon VA, et al. Neurologic autoimmunity and immune checkpoint inhibitors: Autoantibody profiles and outcomes. Neurology. 2020;95(17):e2442-52.

13. Mongay-Ochoa N, Vogrig A, Muñiz-Castrillo S, Honnorat J. AntiHu-associated paraneoplastic syndromes triggered by immunecheckpoint inhibitor treatment. J Neurol. 2020;267(7):2154-6.

14. Gill A, Perez MA, Perrone CM, Bae CJ, Pruitt AA, Lancaster E. A case series of PD-1 inhibitor-associated paraneoplastic neurologic syndromes. J Neuroimmunol. 2019;334:576980.

15. Graus F, Vogrig A, Muñiz-Castrillo S, Antoine JG, Desestret V, Dubey D, et al. Updated Diagnostic Criteria for Paraneoplastic Neurologic Syndromes. Neurol Neuroimmunol Neuroinflamm. 2021;8(4).

16. Vogrig A, Fouret M, Joubert B, Picard G, Rogemond V, Pinto A-L, et al. Increased frequency of anti-Ma2 encephalitis associated with immune checkpoint inhibitors. Neurol Neuroimmunol Neuroinflamm. 2019;6(6):e604.

17. Vogrig A, Gigli GL, Segatti S, Corazza E, Marini A, Bernardini A, et al. Epidemiology of paraneoplastic neurological syndromes: a population-based study. J Neurol. 2020;267(1):26-35.

18. Graus F, Dalmau J. Paraneoplastic neurological syndromes in the era of immune-checkpoint inhibitors. Nat Rev Clin Oncol. 2019;16(9):535-48.

19. Chen DS, Mellman I. Oncology meets immunology: the cancerimmunity cycle. Immunity. 2013;39(1):1-10.

20. Small M, Treilleux I, Couillault C, Pissaloux D, Picard G, Paindavoine S, et al. Genetic alterations and tumor immune attack in Yo paraneoplastic cerebellar degeneration. Acta Neuropathol. 2018;135(4):569-79.

21. Joseph CG, Darrah E, Shah AA, Skora AD, Casciola-Rosen LA, Wigley FM, et al. Association of the autoimmune disease scleroderma with an immunologic response to cancer. Science. 2014;343(6167):152-7.

22. Blachère NE, Orange DE, Santomasso BD, Doerner J, Foo PK, Herre $\mathrm{M}$, et al. T cells targeting a neuronal paraneoplastic antigen mediate tumor rejection and trigger CNS autoimmunity with humoral activation. Eur J Immunol. 2014;44(11):3240-51.

23. Carreno BM, Bennett F, Chau TA, Ling V, Luxenberg D, Jussif J, et al. CTLA-4 (CD152) can inhibit T cell activation by two different mechanisms depending on its level of cell surface expression. J Immunol. 2000;165(3):1352.
24. Okazaki T, Honjo T. The PD-1-PD-L pathway in immunological tolerance. Trends Immunol. 2006;27(4):195-201.

25. Keir ME, Butte MJ, Freeman GJ, Sharpe AH. PD-1 and its ligands in tolerance and immunity. Annu Rev Immunol. 2008;26:677-704.

26. Iwai Y, Ishida M, Tanaka Y, Okazaki T, Honjo T, Minato N. Involvement of PD-L1 on tumor cells in the escape from host immune system and tumor immunotherapy by PD-L1 blockade. Proc Natl Acad Sci. 2002;99(19):12293-7.

27. Okazaki T, Honjo T. PD-1 and PD-1 ligands: from discovery to clinical application. Int Immunol. 2007;19(7):813-24.

28. Ramos-Casals M, Brahmer JR, Callahan MK, Flores-Chávez A, Keegan N, Khamashta MA, et al. Immune-related adverse events of checkpoint inhibitors. Nat Rev Dis Primers. 2020;6(1):38.

29. Yshii LM, Gebauer CM, Pignolet B, Maure E, Queriault C, Pierau M, et al. CTLA4 blockade elicits paraneoplastic neurological disease in a mouse model. Brain. 2016;139(11):2923-34.

30. Osorio JC, Ni A, Chaft JE, Pollina R, Kasler MK, Stephens $\mathrm{D}$, et al. Antibody-mediated thyroid dysfunction during T-cell checkpoint blockade in patients with non-small-cell lung cancer. Ann Oncol. 2017;28(3):583-9.

31. Iwama S, De Remigis A, Callahan MK, Slovin SF, Wolchok JD, Caturegli P. Pituitary expression of CTLA-4 mediates hypophysitis secondary to administration of CTLA-4 blocking antibody. Sci Transl Med. 2014;6(230):230ra45.

32. Caturegli P, Di Dalmazi G, Lombardi M, Grosso F, Larman HB, Larman $\mathrm{T}$, et al. Hypophysitis secondary to cytotoxic T-lymphocyte-associated protein 4 blockade: insights into pathogenesis from an autopsy series. Am J Pathol. 2016;186(12):3225-35.

33. Giometto B, Grisold W, Vitaliani R, Graus F, Honnorat J, Bertolini G. Paraneoplastic neurologic syndrome in the PNS Euronetwork database: a European study from 20 centers. Arch Neurol. 2010;67(3):330-5.

34. Graus F, Keime-Guibert F, Reñe R, Benyahia B, Ribalta T, Ascaso C, et al. Anti-Hu-associated paraneoplastic encephalomyelitis: analysis of 200 patients. Brain. 2001;124(6):1138-48.

35. Yu Z, Kryzer TJ, Griesmann GE, Kim K, Benarroch EE, Lennon VA. CRMP-5 neuronal autoantibody: marker of lung cancer and thymoma-related autoimmunity. Ann Neurol. 2001;49(2):146-54

36. Gadoth A, Kryzer TJ, Fryer J, McKeon A, Lennon VA, Pittock SJ. Microtubule-associated protein 1B: Novel paraneoplastic biomarker. Ann Neurol. 2017;81(2):266-77.

37. Alamowitch S, Graus F, Uchuya M, Rene R, Bescansa E, Delattre JY. Limbic encephalitis and small cell lung cancer. Clinical and immunological features. Brain. 1997;120(Pt 6):923-8.

38. Graus F, Dalmau J. Paraneoplastic neurological syndromes. Curr Opin Neurol. 2012;25(6):795-801.

39. Gultekin SH, Rosenfeld MR, Voltz R, Eichen J, Posner JB, Dalmau J. Paraneoplastic limbic encephalitis: neurological symptoms, immunological findings and tumour association in 50 patients. Brain. 2000;123(Pt 7):1481-94.

40. Dalmau J, Graus F, Villarejo A, Posner JB, Blumenthal D, Thiessen $\mathrm{B}$, et al. Clinical analysis of anti-Ma2-associated encephalitis. Brain. 2004;127(Pt 8):1831-44.

41. Höftberger R, van Sonderen A, Leypoldt F, Houghton D, Geschwind M, Gelfand J, et al. Encephalitis and AMPA receptor antibodies: Novel findings in a case series of 22 patients. Neurology. 2015;84(24):2403-12.

42. Höftberger R, Titulaer MJ, Sabater L, Dome B, Rózsás A, Hegedus B, et al. Encephalitis and GABAB receptor antibodies: novel findings in a new case series of 20 patients. Neurology. 2013;81(17):1500-6.

43. Spatola M, Sabater L, Planagumà J, Martínez-Hernandez E, Armangué T, Prüss H, et al. Encephalitis with mGluR5 antibodies: Symptoms and antibody effects. Neurology. 2018;90(22):e1964-72. 
44. McKeon A, Tracy JA, Pittock SJ, Parisi JE, Klein CJ, Lennon VA. Purkinje cell cytoplasmic autoantibody type 1 accompaniments: the cerebellum and beyond. Arch Neurol. 2011;68(10):1282-9.

45. Bataller L, Wade DF, Graus F, Stacey HD, Rosenfeld MR, Dalmau J. Antibodies to Zic4 in paraneoplastic neurologic disorders and small-cell lung cancer. Neurology. 2004;62(5):778-82.

46. Bernal F, Shams'ili S, Rojas I, Sanchez-Valle R, Saiz A, Dalmau $\mathrm{J}$, et al. Anti-Tr antibodies as markers of paraneoplastic cerebellar degeneration and Hodgkin's disease. Neurology. 2003;60(2):230-4.

47. Peterson K, Rosenblum MK, Kotanides H, Posner JB. Paraneoplastic cerebellar degeneration. I. A clinical analysis of 55 antiYo antibody-positive patients. Neurology. 1992;42(10):1931-7.

48. Pang KK, de Sousa C, Lang B, Pike MG. A prospective study of the presentation and management of dancing eye syndrome/ opsoclonus-myoclonus syndrome in the United Kingdom. Eur J Paediatr Neurol. 2010;14(2):156-61.

49. Armangué T, Sabater L, Torres-Vega E, Martínez-Hernández E, Ariño H, Petit-Pedrol M, et al. Clinical and immunological features of opsoclonus-myoclonus syndrome in the era of neuronal cell surface antibodies. JAMA Neurol. 2016;73(4):417-24.

50. Dubey D, Jitprapaikulsan J, Bi H, Do Campo RV, McKeon A, Pittock SJ, et al. Amphiphysin-IgG autoimmune neuropathy A recognizable clinicopathologic syndrome. Neurology. 2019;93(20):e1873-80.

51. Camdessanché JP, Antoine JC, Honnorat J, Vial C, Petiot P, Convers $\mathrm{P}$, et al. Paraneoplastic peripheral neuropathy associated with anti-Hu antibodies: A clinical and electrophysiological study of 20 patients. Brain. 2002;125(1):166-75.

52. Dubey D, Lennon VA, Gadoth A, Pittock SJ, Flanagan EP, Schmeling JE, et al. Autoimmune CRMP5 neuropathy phenotype and outcome defined from 105 cases. Neurology. 2018;90(2):e103-10.

53. Lee HR, Lennon VA, Camilleri M, Prather CM. Paraneoplastic gastrointestinal motor dysfunction: clinical and laboratory characteristics. Am J Gastroenterol. 2001;96(2):373-9.

54. Lennon VA, Kryzer TJ, Griesmann GE, O'Suilleabhain PE, Windebank AJ, Woppmann A, et al. Calcium-channel antibodies in the Lambert-Eaton syndrome and other paraneoplastic syndromes. N Engl J Med. 1995;332(22):1467-74.

55. Graus F, Vincent A, Pozo-Rosich P, Sabater L, Saiz A, Lang $\mathrm{B}$, et al. Anti-glial nuclear antibody: marker of lung cancerrelated paraneoplastic neurological syndromes. J Neuroimmunol. 2005;165(1-2):166-71.

56. Malter MP, Helmstaedter C, Urbach H, Vincent A, Bien CG. Antibodies to glutamic acid decarboxylase define a form of limbic encephalitis. Ann Neurol. 2010;67(4):470-8.

57. Tanaka M, Tanaka K, Idezuka J, Tsuji S. Failure to detect cytotoxic $\mathrm{T}$ cell activity against recombinant Yo protein using autologous dendritic cells as the target in a patient with paraneoplastic cerebellar degeneration and anti-Yo antibody. Exp Neurol. 1998;150(2):337-8.

58. Bien CG, Vincent A, Barnett MH, Becker AJ, Blümcke I, Graus F, et al. Immunopathology of autoantibody-associated encephalitides: clues for pathogenesis. Brain. 2012;135(Pt 5):1622-38.

59. Kreye J, Wenke NK, Chayka M, Leubner J, Murugan R, Maier $\mathrm{N}$, et al. Human cerebrospinal fluid monoclonal N-methyl-Daspartate receptor autoantibodies are sufficient for encephalitis pathogenesis. Brain. 2016;139(Pt 10):2641-52.

60. Flanagan EP, Hinson SR, Lennon VA, Fang B, Aksamit AJ, Morris $\mathrm{PP}$, et al. Glial fibrillary acidic protein immunoglobulin $\mathrm{G}$ as biomarker of autoimmune astrocytopathy: Analysis of 102 patients. Ann Neurol. 2017;81(2):298-309.

61. Titulaer MJ, McCracken L, Gabilondo I, Armangué T, Glaser C, Iizuka $\mathrm{T}$, et al. Treatment and prognostic factors for long-term outcome in patients with anti-NMDA receptor encephalitis: an observational cohort study. Lancet Neurol. 2013;12(2):157-65.
62. Lancaster E, Martinez-Hernandez E, Titulaer MJ, Boulos M, Weaver $\mathrm{S}$, Antoine JC, et al. Antibodies to metabotropic glutamate receptor 5 in the Ophelia syndrome. Neurology. 2011;77(18):1698-701.

63. Dalmau J, Geis C, Graus F. Autoantibodies to synaptic receptors and neuronal cell surface proteins in autoimmune diseases of the central nervous system. Physiol Rev. 2017;97(2):839-87.

64. Vogrig A, Muñiz-Castrillo S, Joubert B, Picard G, Rogemond $\mathrm{V}$, Marchal C, et al. Central nervous system complications associated with immune checkpoint inhibitors. J Neurol Neurosurg Psychiatry. 2020;91(7):772-8.

65. Brown MP, Hissaria P, Hsieh AH, Kneebone C, Vallat W. Autoimmune limbic encephalitis with anti-contactin-associated protein-like 2 antibody secondary to pembrolizumab therapy. $\mathbf{J}$ Neuroimmunol. 2017;305:16-8.

66. Nakatani Y, Tanaka N, Enami T, Minami S, Okazaki T, Komuta K. Lambert-Eaton myasthenic syndrome caused by nivolumab in a patient with squamous cell lung cancer. Case Rep Neurol. 2018;10(3):346-52.

67. Basal E, Zalewski N, Kryzer TJ, Hinson SR, Guo Y, Dubey D, et al. Paraneoplastic neuronal intermediate filament autoimmunity. Neurology. 2018;91(18):e1677-89.

68. Zekeridou A, Kryzer T, Guo Y, Hassan A, Lennon V, Lucchinetti CF, et al. Phosphodiesterase 10A IgG A novel biomarker of paraneoplastic neurologic autoimmunity. Neurology. 2019;93(8):e815-22.

69. Prüss H. Autoantibodies in neurological disease. Nat Rev Immunol. 2021.

70. Dubey D, David WS, Reynolds KL, Chute DF, Clement NF, Cohen $\mathrm{JV}$, et al. Severe neurological toxicity of immune checkpoint inhibitors: growing spectrum. Ann Neurol. 2020;87(5):659-69.

71. Yuan J, Page DB, Ku GY, Li Y, Mu Z, Ariyan C, et al. Correlation of clinical and immunological data in a metastatic melanoma patient with heterogeneous tumor responses to ipilimumab therapy. Cancer Immun. 2010;10:1.

72. Schreiber RD, Old LJ, Smyth MJ. Cancer immunoediting: integrating immunity's roles in cancer suppression and promotion. Science. 2011;331(6024):1565-70.

73. Manson G, Maria ATJ, Poizeau F, Danlos FX, Kostine M, Brosseau $\mathrm{S}$, et al. Worsening and newly diagnosed paraneoplastic syndromes following anti-PD-1 or anti-PD-L1 immunotherapies, a descriptive study. J Immunother Cancer. 2019;7(1):337.

74. Makarious D, Horwood K, Coward JIG. Myasthenia gravis: An emerging toxicity of immune checkpoint inhibitors. Eur J Cancer. 2017;82:128-36.

75. Graus F, Escudero D, Oleaga L, Bruna J, Villarejo-Galende A, Ballabriga J, et al. Syndrome and outcome of antibody-negative limbic encephalitis. Eur J Neurol. 2018;25(8):1011-6.

76. van Sonderen A, Thijs RD, Coenders EC, Jiskoot LC, Sanchez E, de Bruijn MA, et al. Anti-LGI1 encephalitis: Clinical syndrome and long-term follow-up. Neurology. 2016;87(14):1449-56.

77. Lawn ND, Westmoreland BF, Kiely MJ, Lennon VA, Vernino S. Clinical, magnetic resonance imaging, and electroencephalographic findings in paraneoplastic limbic encephalitis. Mayo Clin Proc. 2003;78(11):1363-8.

78. Williams TJ, Benavides DR, Patrice KA, Dalmau JO, de Avila AL, Le DT, et al. Association of autoimmune encephalitis with combined immune checkpoint inhibitor treatment for metastatic cancer. JAMA Neurol. 2016;73(8):928-33.

79. Larkin J, Chmielowski B, Lao CD, Hodi FS, Sharfman W, Weber J, et al. Neurologic serious adverse events associated with nivolumab plus ipilimumab or nivolumab alone in advanced melanoma, including a case series of encephalitis. Oncologist. 2017;22(6):709-18.

80. Shah S, Dunn-Pirio A, Luedke M, Morgenlander J, Skeen M, Eckstein C. Nivolumab-induced autoimmune encephalitis in two patients with lung adenocarcinoma. Case Rep Neurol Med. 2018;2018:2548528. 
81. Papadopoulos KP, Romero RS, Gonzalez G, Dix JE, Lowy I, Fury M. Anti-hu-associated autoimmune limbic encephalitis in a patient with PD-1 inhibitor-responsive myxoid chondrosarcoma. Oncologist. 2018;23(1):118-20.

82. Fellner A, Makranz C, Lotem M, Bokstein F, Taliansky A, Rosenberg S, et al. Neurologic complications of immune checkpoint inhibitors. J Neurooncol. 2018;137(3):601-9.

83. Hottinger AF, de Micheli R, Guido V, Karampera A, Hagmann P, Du Pasquier R. Natalizumab may control immune checkpoint inhibitor-induced limbic encephalitis. Neurol Neuroimmunol Neuroinflamm. 2018;5(2):e439.

84. Seki M, Suzuki S, Iizuka T, Shimizu T, Nihei Y, Suzuki N, et al. Neurological response to early removal of ovarian teratoma in anti-NMDAR encephalitis. J Neurol Neurosurg Psychiatry. 2008;79(3):324-6.

85. Dalmau J, Lancaster E, Martinez-Hernandez E, Rosenfeld MR, Balice-Gordon R. Clinical experience and laboratory investigations in patients with anti-NMDAR encephalitis. Lancet Neurol. 2011;10(1):63-74.

86. Valencia-Sanchez C, Zekeridou A. Paraneoplastic Neurological Syndromes and Beyond Emerging With the Introduction of Immune Checkpoint Inhibitor Cancer Immunotherapy. Front Neurol. 2021;12(494).

87. Wei X, Walia V, Lin JC, Teer JK, Prickett TD, Gartner J, et al. Exome sequencing identifies GRIN2A as frequently mutated in melanoma. Nat Genet. 2011;43(5):442-6.

88. Prickett TD, Zerlanko BJ, Hill VK, Gartner JJ, Qutob N, Jiang $\mathrm{J}$, et al. Somatic mutation of GRIN2A in malignant melanoma results in loss of tumor suppressor activity via aberrant NMDAR complex formation. J Invest Dermatol. 2014;134(9):2390-8.

89. Naito T, Osaki M, Ubano M, Kanzaki M, Uesaka Y. Acute cerebellitis after administration of nivolumab and ipilimumab for small cell lung cancer. Neurol Sci. 2018;39(10):1791-3.

90. Zurko J, Mehta A. Association of immune-mediated cerebellitis with immune checkpoint inhibitor therapy. Mayo Clin Proc Innov Qual Outcomes. 2018;2(1):74-7.

91. Kawamura R, Nagata E, Mukai M, Ohnuki Y, Matsuzaki T, Ohiwa $\mathrm{K}$, et al. Acute cerebellar ataxia induced by nivolumab. Intern Med. 2017;56(24):3357-9.

92. Dalmau J, Rosenfeld MR. Paraneoplastic syndromes of the CNS. Lancet Neurol. 2008;7(4):327-40.

93. Bataller L, Graus F, Saiz A, Vilchez JJ, Group ftSOMS. Clinical outcome in adult onset idiopathic or paraneoplastic opsoclonusmyoclonus. Brain. 2001;124(2):437-43.

94. Maller B, Peguero E, Tanvetyanon T. Ipilimumab/Nivolumabrelated opsoclonus-myoclonus-ataxia syndrome variant in a patient with malignant pleural mesothelioma. J Immunother (Hagerstown, Md : 1997). 2018;41(9):411-2.

95. Dubey D, David WS, Amato AA, Reynolds KL, Clement NF, Chute DF, et al. Varied phenotypes and management of immune checkpoint inhibitor-associated neuropathies. Neurology. 2019;93(11):e1093-103.

96. Touat M, Talmasov D, Ricard D, Psimaras D. Neurological toxicities associated with immune-checkpoint inhibitors. Curr Opin Neurol. 2017;30(6):659-68.

97. Gill AJ, Gandhy S, Lancaster E. Nivolumab-associated LambertEaton myasthenic syndrome and cerebellar dysfunction in a patient with a neuroendocrine tumor. Muscle Nerve. 2021;63(3):E18-21.

98. Anderson C, Guidon A, Khan F, Thomas A, Riehle C, Hehir M, et al. Case Report of Lambert Eaton Myasthenic Syndrome in a Patient with Small Cell Lung Cancer on Immune Checkpoint Inhibitor Therapy. OBM Neurobiol. 2021;5.

99. Brahmer JR, Lacchetti C, Schneider BJ, Atkins MB, Brassil KJ, Caterino JM, et al. Management of immune-related adverse events in patients treated with immune checkpoint inhibitor therapy: American Society of Clinical Oncology Clinical Practice Guideline. J Clin Oncol. 2018;36(17):1714-68.

100. Thompson JA, Schneider BJ, Brahmer J, Andrews S, Armand P, Bhatia S, et al. Management of Immunotherapy-Related Toxicities, Version 1.2019. J Natl Compr Canc Netw. 2019;17(3):255-89. Available from: https://www.nccn.org/professionals/physician_gls/ default.aspx\#immunotherapy.

101. Haanen J, Carbonnel F, Robert C, Kerr KM, Peters S, Larkin J, et al. Management of toxicities from immunotherapy: ESMO Clinical Practice Guidelines for diagnosis, treatment and followup. Ann Oncol. 2017;28(suppl_4):119-42.

102. Puzanov I, Diab A, Abdallah K, Bingham CO 3rd, Brogdon C, Dadu R, et al. Managing toxicities associated with immune checkpoint inhibitors: consensus recommendations from the Society for Immunotherapy of Cancer (SITC) Toxicity Management Working Group. J Immunother Cancer. 2017;5(1):95.

103. National Cancer Institute. CTCAE v5.0 Quick Reference 8.5x11. 2017. [March 20, 2019]. Available from: https://ctep. cancer.gov/protocolDevelopment/electronic_applications/docs/ CTCAE_v5_Quick_Reference_8.5x11.pdf.

104. Horvat TZ, Adel NG, Dang TO, Momtaz P, Postow MA, Callahan MK, et al. Immune-related adverse events, need for systemic immunosuppression, and effects on survival and time to treatment failure in patients with melanoma treated with ipilimumab at Memorial Sloan Kettering Cancer Center. J Clin Oncol. 2015;33(28):3193-8.

105. Abu-Sbeih H, Tang T, Ali F, Johnson D, Qiao W, Diab A, et al. The impact of immune checkpoint inhibitor-related adverse events and their immunosuppressive treatment on patients' outcomes. Journal of Immunotherapy and Precision Oncology. 2018;1(1):7-18.

106. Brahmer JR, Abu-Sbeih H, Ascierto PA, Brufsky J, Cappelli LC, Cortazar FB, et al. Society for Immunotherapy of Cancer (SITC) clinical practice guideline on immune checkpoint inhibitorrelated adverse events. J Immunother Cancer. 2021;9(6):e002435.

107. Weber MS, Prod'homme T, Patarroyo JC, Molnarfi N, Karnezis T, Lehmann-Horn K, et al. B-cell activation influences T-cell polarization and outcome of anti-CD20 B-cell depletion in central nervous system autoimmunity. Ann Neurol. 2010;68(3):369-83.

108. Graf J, Mares J, Barnett M, Aktas O, Albrecht P, Zamvil SS, et al. Targeting B cells to modify MS, NMOSD, and MOGAD. Part 1. Neurol Neuroimmunol Neuroinflamm. 2021;8(1):e918.

109. Lee W-J, Lee S-T, Byun J-I, Sunwoo J-S, Kim T-J, Lim J-A, et al. Rituximab treatment for autoimmune limbic encephalitis in an institutional cohort. Neurology. 2016;86(18):1683-91.

110. Whittam DH, Tallantyre EC, Jolles S, Huda S, Moots RJ, Kim $\mathrm{HJ}$, et al. Rituximab in neurological disease: principles, evidence and practice. Pract Neurol. 2019;19(1):5.

111. Shah S, Dunn-Pirio A, Luedke M, Morgenlander J, Skeen M, Eckstein C. Nivolumab-induced autoimmune encephalitis in two patients with lung adenocarcinoma. Case Rep Neurol Med. 2018;2018:4.

112. Ito M, Fujiwara S, Fujimoto D, Mori R, Yoshimura H, Hata A, et al. Rituximab for nivolumab plus ipilimumab-induced encephalitis in a small-cell lung cancer patient. Ann Oncol. 2017;28(9):2318-9.

113. Lee B, Wong A, Kee D, Neeson P, Shackleton M, McArthur G, et al. The use of ipilimumab in patients with rheumatoid arthritis and metastatic melanoma. Ann Oncol. 2016;27(6):1174-7.

114. Engelhardt B, Kappos L. Natalizumab: targeting $\alpha_{4}$-integrins in multiple sclerosis. Neurodegener Dis. 2008;5(1):16-22.

115. Emadi A, Jones RJ, Brodsky RA. Cyclophosphamide and cancer: golden anniversary. Nat Rev Clin Oncol. 2009;6(11):638-47.

116. Keime-Guibert F, Graus F, Fleury A, René R, Honnorat $\mathrm{J}$, Broet $\mathrm{P}$, et al. Treatment of paraneoplastic neurological syndromes with antineuronal antibodies (Anti-Hu, Anti-Yo) with a combination of immunoglobulins, cyclophosphamide, 
and methylprednisolone. J Neurol Neurosurg Psychiatry. 2000;68(4):479-82.

117. Vernino S, O’Neill BP, Marks RS, O’Fallon JR, Kimmel DW. Immunomodulatory treatment trial for paraneoplastic neurological disorders. Neuro Oncol. 2004;6(1):55-62.

118. Kunchok A, Zekeridou A, Pittock S. CRMP5-IgG-Associated Paraneoplastic Myelopathy With PD-L1 Inhibitor Therapy. JAMA Neurol. 2020;77(2):255-6.

119. Tedder TF. CD19: a promising B cell target for rheumatoid arthritis. Nat Rev Rheumatol. 2009;5(10):572-7.

120. Chen D, Gallagher S, Monson NL, Herbst R, Wang Y. Inebilizumab, a B cell-depleting anti-CD19 antibody for the treatment of autoimmune neurological diseases: insights from preclinical studies. J Clin Med. 2016;5(12):107.

121. Cree BAC, Bennett JL, Kim HJ, Weinshenker BG, Pittock SJ, Wingerchuk DM, et al. Inebilizumab for the treatment of neuromyelitis optica spectrum disorder (N-MOmentum): a doubleblind, randomised placebo-controlled phase $2 / 3$ trial. Lancet. 2019;394(10206):1352-63.

122. Hu Y, Turner MJ, Shields J, Gale MS, Hutto E, Roberts BL, et al. Investigation of the mechanism of action of alemtuzumab in a human CD52 transgenic mouse model. Immunology. 2009;128(2):260-70.

123. Cox AL, Thompson SAJ, Jones JL, Robertson VH, Hale G, Waldmann H, et al. Lymphocyte homeostasis following therapeutic lymphocyte depletion in multiple sclerosis. Eur J Immunol. 2005;35(11):3332-42.

124. Coles AJ, Twyman CL, Arnold DL, Cohen JA, Confavreux C, Fox EJ, et al. Alemtuzumab for patients with relapsing multiple sclerosis after disease-modifying therapy: a randomised controlled phase 3 trial. Lancet. 2012;380(9856):1829-39.

125. Espandar L, O’Brien S, Thirkill C, Lubecki L, Esmaeli B. Successful treatment of cancer-associated retinopathy with alemtuzumab. J Neurooncol. 2007;83:295-302.

126. Bech R, Baumgartner-Nielsen J, Peterslund NA, Steiniche T, Deleuran M, d'Amore F. Alemtuzumab is effective against severe chronic lymphocytic leukaemia-associated paraneoplastic pemphigus. Br J Dermatol. 2013;169(2):469-72.

127. Kim JH, Kim S-C. Paraneoplastic pemphigus: paraneoplastic autoimmune disease of the skin and mucosa. Front Immunol. 2019;10(1259).

128. Jones JL, Phuah CL, Cox AL, Thompson SA, Ban M, Shawcross J, et al. IL-21 drives secondary autoimmunity in patients with multiple sclerosis, following therapeutic lymphocyte depletion with alemtuzumab (Campath-1H). J Clin Investig. 2009;119(7):2052-61.

129. Tuohy O, Costelloe L, Hill-Cawthorne G, Bjornson I, Harding K, Robertson N, et al. Alemtuzumab treatment of multiple sclerosis: long-term safety and efficacy. J Neurol Neurosurg Psychiatry. 2015;86(2):208-15.

130. Roopenian DC, Christianson GJ, Sproule TJ, Brown AC, Akilesh $\mathrm{S}$, Jung N, et al. The MHC class I-like IgG receptor controls perinatal IgG transport, IgG homeostasis, and fate of IgG-Fc-coupled drugs. J Immunol. 2003;170(7):3528-33.

131. Chaudhury C, Mehnaz S, Robinson JM, Hayton WL, Pearl DK, Roopenian DC, et al. The major histocompatibility complexrelated $\mathrm{Fc}$ receptor for $\mathrm{IgG}(\mathrm{FcRn})$ binds albumin and prolongs its lifespan. J Exp Med. 2003;197(3):315-22.

132. Bril V, Benatar M, Andersen H, Vissing J, Brock M, Greve B, et al. Efficacy and safety of rozanolixizumab in moderate to severe generalized myasthenia gravis: a phase 2 randomized control trial. Neurology. 2021;96(6):e853-65.

133. Howard JF, Bril V, Burns TM, Mantegazza R, Bilinska M, Szczudlik A, et al. Randomized phase 2 study of FcRn antagonist efgartigimod in generalized myasthenia gravis. Neurology. 2019;92(23):e2661-73.
134. Chihara N, Aranami T, Sato W, Miyazaki Y, Miyake S, Okamoto $\mathrm{T}$, et al. Interleukin 6 signaling promotes anti-aquaporin 4 autoantibody production from plasmablasts in neuromyelitis optica. Proc Natl Acad Sci U S A. 2011;108(9):3701-6.

135. Kieseier BC, Stüve O, Dehmel T, Goebels N, Leussink VI, Mausberg AK, et al. Disease amelioration with tocilizumab in a treatment-resistant patient with neuromyelitis optica: implication for cellular immune responses. JAMA Neurol. 2013;70(3):390-3.

136. Yamamura T, Kleiter I, Fujihara K, Palace J, Greenberg B, Zakrzewska-Pniewska B, et al. Trial of satralizumab in neuromyelitis optica spectrum disorder. N Engl J Med. 2019;381(22):2114-24.

137. Araki M. Blockade of IL-6 signaling in neuromyelitis optica. Neurochem Int. 2019;130:104315.

138. Picca A, Valyraki N, Birzu C, Kramkimel N, Hermine O, Zahr N, et al. Anti-Interleukin- 6 and Janus Kinase Inhibitors for Severe Neurologic Toxicity of Checkpoint Inhibitors. Neurol Neuroimmunol Neuroinflamma. 2021;8(6):e1073.

139. Stroud CR, Hegde A, Cherry C, Naqash AR, Sharma N, Addepalli $\mathrm{S}$, et al. Tocilizumab for the management of immune mediated adverse events secondary to PD-1 blockade. J Oncol Pharm Pract. 2019;25(3):551-7.

140. Igawa T, Ishii S, Tachibana T, Maeda A, Higuchi Y, Shimaoka $\mathrm{S}$, et al. Antibody recycling by engineered $\mathrm{pH}$-dependent antigen binding improves the duration of antigen neutralization. Nat Biotechnol. 2010;28(11):1203-7.

141. Uzawa A, Mori M, Sato Y, Masuda S, Kuwabara S. CSF interleukin-6 level predicts recovery from neuromyelitis optica relapse. J Neurol Neurosurg Psychiatry. 2012;83(3):339-40.

142. Zhou Y, Gong B, Lin F, Rother RP, Medof ME, Kaminski HJ. Anti-C5 antibody treatment ameliorates weakness in experimentally acquired myasthenia gravis. J Immunol. 2007;179(12):8562-7.

143. Tüzün E, Scott BG, Goluszko E, Higgs S, Christadoss P. Genetic evidence for involvement of classical complement pathway in induction of experimental autoimmune myasthenia gravis. $\mathbf{J}$ Immunol. 2003;171(7):3847-54.

144. Soltys J, Kusner LL, Young A, Richmonds C, Hatala D, Gong B, et al. Novel complement inhibitor limits severity of experimentally myasthenia gravis. Ann Neurol. 2009;65(1):67-75.

145. Duan T, Smith AJ, Verkman AS. Complement-dependent bystander injury to neurons in AQP4-IgG seropositive neuromyelitis optica. J Neuroinflammation. 2018;15(1):294.

146. Howard JF Jr, Utsugisawa K, Benatar M, Murai H, Barohn RJ, Illa I, et al. Safety and efficacy of eculizumab in anti-acetylcholine receptor antibody-positive refractory generalised myasthenia gravis (REGAIN): a phase 3, randomised, double-blind, placebo-controlled, multicentre study. Lancet Neurol. 2017;16(12):976-86.

147. Pittock SJ, Berthele A, Fujihara K, Kim HJ, Levy M, Palace J, et al. Eculizumab in aquaporin-4-positive neuromyelitis optica spectrum disorder. N Engl J Med. 2019;381(7):614-25.

148. Röth A, Rottinghaus ST, Hill A, Bachman ES, Kim JS, Schrezenmeier $\mathrm{H}$, et al. Ravulizumab (ALXN1210) in patients with paroxysmal nocturnal hemoglobinuria: results of 2 phase $1 \mathrm{~b} / 2$ studies. Blood Adv. 2018;2(17):2176-85.

149. Rondeau E, Scully M, Ariceta G, Barbour T, Cataland S, Heyne $\mathrm{N}$, et al. The long-acting C5 inhibitor, Ravulizumab, is effective and safe in adult patients with atypical hemolytic uremic syndrome naïve to complement inhibitor treatment. Kidney Int. 2020;97(6):1287-96.

Publisher's Note Springer Nature remains neutral with regard to jurisdictional claims in published maps and institutional affiliations. 